特 集

\title{
レーザーイオン化分光法のプラズマプロセス分野への応用
}

\section{岡田龍雄* ・前田三男*}

\author{
(1989年 6 月 14 日 受理)
}

\section{Applications of Laser Ionization Spectroscopy to Plasma Processing and its Related Fields}

\author{
Tatsuo OKADA* and Mitsuo MAEDA*
}

(Received June 14, 1989)

\begin{abstract}
Laser ionization spectroscopy (LIS) is known as a very sensitive technique for detection of atoms and molecules. Its applications to plasma processing and related fields are reviewed. Main topics are on the detection and the measurement of nonfluorescent radicals like $\mathrm{CH}_{3}$ and $\mathrm{SiH}_{3}$ in elementary processes by resonance ionization spectroscopy (RIS). Applications of LIS to surface characterization are also described briefly.
\end{abstract}

Key Words : Laser ionization spectroscopy, Resonance ionization spectroscopy, Radical, Plasma processing, Surface characterization.

\section{1.はじめに}

レーザー光の持つ高度のコヒーレンス（単色 性, 指向性, 集光性) と高い輝度は分光用光源 として理想的な特性であり，色素レーザーに代 表される波長可変レーザーの実用化とともに， レーザー分光法が著しい進歩を遂げた1)。従来 のインコヒーレントな光源の代わりにレーザー を用いることにより，スペクトル，空間，時間 分解能が大幅に改善され, 粒子の検出感度も著 しく向上した。またレーザーの高いパワー密 度を利用した多光子励起や誘導ラマン散乱法な ど各種の非線形分光法も，レーザー分光法を一 段と魅力あるものにしている。

レーザー分光法は, 原子・分子の構造や相互 作用を精密に測定するという基礎的な分野でま ず著しい成果を収めた。その後分析化学, 燃焼 計測, 反応過程の計測, 環境計測, 生体計測な
どさまざまな分野に応用されるようになった。 プラズマ計測においても，レーザー分光法は高 い時間・空間分解能で高感度な粒子の検出が可 能であり，また高いスペクトル分解能を利用し て電界・磁界・温度などの物理量の計測も可能 なため, 今日有力な地位を占めるようになった。 特に, 多種多様な原子・分子のその場計測が求 められるプロセスプラズマ自身の計測やそれに 関連する素過程の計測は, レーザー分光法が最 も威力を発揮できる対象である ${ }^{2-4)}$ 本稿ではレーザー分光法のうち, レーザーイ オン化分光法 (LIS: Laser Ionization Spectroscopy）のプラズマプロセス分野への応用に ついて解説している。LIS は，非共鳴イオン化 を利用するものと共鳴イオン化を利用するもの に大別できる。このうち共鳴イオン化法（R I $\mathrm{S}$ : Resonance Ionization Spectroscopy)は, 波長可変レーザーを用いて原子・分子を選択的 
に励起し，さらにこれをイオン化して生成した 電子・イオン対を検知して, 原子・分子の検出 を行なう ${ }^{5,6)}$ 。

RIS は，数あるレーザー分光法の中でも最も 高い検出感度を示し，極限的には「単一原子検 知」も可能である。しかしこの方法をプラズマ 内の粒子に適用して直接イオンを検出すること は，既に多量に存在するイオンの干渉を受ける ため困難である。従って, 時間・空間分解能に 優れた RIS の有用性が生かせるのは，プラズ マ中での計測を必ずしも必要としない反応定数 の測定など，むしろ素過程の研究と考えられる。 特に，プラズマ C V D による炭素膜やシリコン 膜の作成で重要視されているメチル $\left(\mathrm{CH}_{3}\right)$ や シリル $\left(\mathrm{SiH}_{3}\right)$ は非発光性であるためレーザ 一誘起蛍光法（LIF） などでは計測できないが, RISによればこれらを感度良く検出することが できるので注目されている。

RIS をプラズマ中の粒子検出に適用した場合, イオン化に伴ってプラズマパラメーターが変化 し, 電流・電圧の変化としてイオン化を間接的 に検出できる。これは，オプトガルバニック分 光と呼ばれ?, プラズマ中での RIS 信号の検出 法の一種と見ることができる。オプトガルバ二 ック法は，その簡便さのためにすでにプロセス プラズマ計測の重要な手法となっているが8-10), これについてはこの特集号でも電界計測など の項で取り上げられているので，詳細は省略す る。

一方，強いレーザー光を気体原子に集光すれ ばRIS を利用しなくても非共鳴多光子イオン化 が起こる。また，レーザー光を固体表面に集光 照射すると，固体原子を瞬時にプラズマにする こともできる。このようなレーザーイオン化に 質量分析器を組み合わせたレーザー質量分析法 (LIMS: Laser Ionization Mass Spectroscopy）は，気相中のラジカル検出だけでなく， 薄膜や表面の分析など材料のキャラクタリゼ一 ション法として広く用いられている11。

本稿ではレーザーイオン化法のうち RISによ る非発光性ラジカルの測定を中心に述べる。ま
ず，2 節で RIS の原理と特徴について簡単に述 ベた後，CVD プロセスで重要視されている。 $\mathrm{CH}_{3}, \mathrm{SiH}_{3}$ などの非発光性ラジカルのRISに よる検出例を紹介する（3 節）。4 節で我々の 行なっている $\mathrm{CH}_{3}$ の例を中心に, RISの反応素 過程計測への応用について述べる。またレー ザーイオン化法の材料キャラクタリゼーション への応用について，5節で若干の紹介をする。

\section{2. レーザー共喘イオン化法（RIS）}

RISでは，原子や分子を励起状態を経由して 共鳴的に光イオン化を行ない, 発生した電子 ・ イオン対を検知することにより原子や分子の検 出を行なう。RISについては優れた解説や成書 があるので, 詳細はそれらを参考して頂きたい ${ }^{5,6)}$ ここでは, RIS の原理と特徴について簡単に述 ベる。

RIS に用いる光イオン化過程には，種々のスキ 一ムが考えられる。Fig. 1 にHurst らによる 代表的なイオン化スキームを示す。高出力のパ ルスレーザーを用いた場合, 通常の 1 光子励起 だけでなく 2 (多) 光子励起により一気に高い

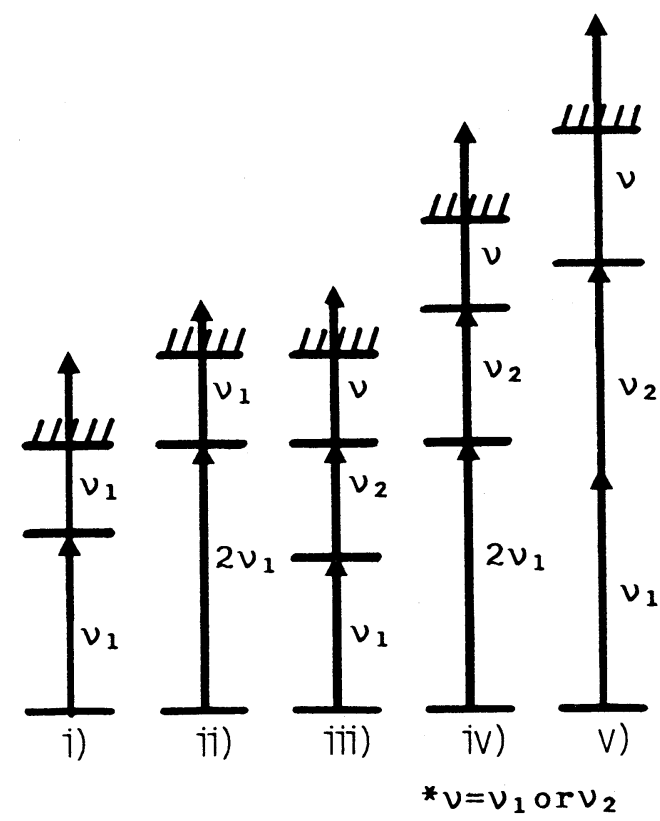

Fig. 1 Energy level diagrams for RIS schemes. ${ }^{6)}$ 
準位に励起することができる。励起原子は，さ らに光子を吸収して，直接または 2 （多）段階 的にイオン化される。イオン化に際して，自動 イオン化準位やリュードベルグ状態からの電界 イオン化を利用すれば，効率よくイオン化を行 なうことができる。どのようなスキームを用い るかは, エネルギー準位 (励起波長) やイオン 化効率を考慮して最適なものを選べば良い。

RIS 用の励起光源には, 出力が大きく可变波 長域が広いエキシマーレーザー励起あるいは Nd: YAG レーザー励起の色素レーザーが適し ている。このような高出力色素レーザーでは, 例えば最近開発された非線形光学結晶 $\beta-\mathrm{BaB}_{2}$ $\mathrm{O}_{4}(\mathrm{BBO})$ を用いて第 2 高調波を発生させると, 波長205 $\mathrm{nm}$ 程度までは容易に可変波長域を拡 張することができる ${ }^{12,13)}$ 。このような光源に 2

（多）光子励起を併用すれば，一部の希ガスや 水素分子を除くほとんど全ての原子・分子を励 起できる。

イオン化用レーザーとしては, 適当なエネル ギー準位を選んでおけば，励起レーザー光をそ のまま用いることができ（Fig. 1 i ），ii)，， 一 台のレーザーで斉むので都合が良い。イオン化 効率を高めたり, イオン化の選択性を高めるに は, さらに高いエネルギー準位を経由してイオ ン化を行なえば良い（Fig.1 iii ），iv)）。この場 合にはイオン化用にも波長可変レーザーが必要 になる。一方, 励起用とイオン化用に 2 台のレ 一ザーを用いて，ビーム交差法を用いると空間 分解能を高く取れる利点がある。

イオン化により生じた電子・イオン対の検出 には 2 次電子增倍管, 比例計数管, 細線や平板 などプロープ電極や, 熱イオン検出器などが用 いられる。RISで最も高い感度が得られるのは, 高い量子効率でイオン化し, それを S N 比の高 い2 次電子增倍管などで直接検出した場合であ る。他のイオンの干渉がある場合にはフィル夕 一として質量分析器を用いることが多い。2 次 電子増倍管は高真空条件下での動作に限られる が個数オーダのイオンを検知できる。これに対 してプローブ電極方式は, 真空から大気圧まで
の広い圧力範囲と種々のガス雾囲気の中で利用 できる。この場合でもガス中でのイオンの再結 合などがなければイオン数で1000個オーダの検 出感度が得られる。

プラズマ中の粒子にRISを適用すると， イ オン化に伴ってプラズマのインピーダンスが変 化し，オプトガルバニック効果による間接的な 検出ができる。プラズマ中でレーザーにより生 成されたイオンを直接検知した例はないようで ある。

\section{RISによるラジカルの検出}

本節では，プラズマ CVD に関連する中性 粒 子のうち， RISによる検出が最も期待されてい る $\mathrm{CH}_{3}, \mathrm{SiH}_{3}$ などの非発光性ラジカルの検出 について紹介する。これらのラジカルは, $\mathrm{Si}$ 膜や炭素膜生成時のキーラジカルの一つと考え られている。

\section{$3.1 \mathrm{CH}_{3}$ ラジカル}

RISによる $\mathrm{CH}_{3}$ ラジカルの最初の検出は, Lin らのグループにより報告されている Fig. 2 に彼らの検出装置を示す。 $\mathrm{CH}_{3}$ は, メ

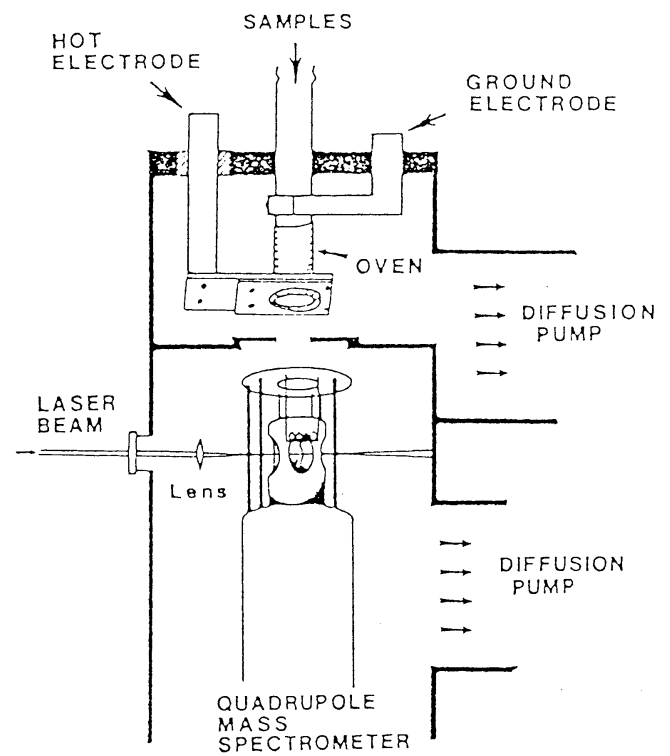

Fig. 2 Schematic of the resonant ionization mass spectrometer used for detection of $\mathrm{CH}_{3}{ }^{14)}$. 
チル基を含む母材ガス （dimethyl-sulfoxide や $\mathrm{CH}_{3} \mathrm{I}$ など）を，タンタルオーブン中で熱解 離して発生している。発生した $\mathrm{CH}_{3}$ ラジカルは, $3 \times 10^{-7}$ Torr に保った 4 重極質量分析器 $(\mathrm{Q}$ M) 室に導入され，QMのイオン化部において 波長 $450.9 \mathrm{~nm}$ のレーザー光により， 3 光子共 鳴 4 光子イオン化 (以後 $3+1$ イオン化のよう に記述する）によりイオン化される。イオン化 部での $\mathrm{CH}_{3}$ ラジカルの密度は, その背圧から $10^{10}$ $\sim 10^{11} \mathrm{~cm}^{-3}$ 程度と推定されている。光源には, Nd: YAGレーザー励起の色素レーザーを用い, その出力エネルギーは $12 \mathrm{~mJ} /$ パルス, スペクト ル幅 $0.5 \mathrm{~cm}^{-1}$ である。これを焦点距離 $50 \mathrm{~mm} の$ レンズで集光して用いている。このようにして 見い出された RIS スペクトルの遷多波長を Table I に示す。これらの遷移は, 前述の 例 とは異なり，2+1イオン化過程によるものと 同定されている ${ }^{15,16)}$ 。

この実験で質量分析器は背景イオンを除去す るフィルターの役目をしている。質量分析器は, C V Dプラズマの粒子組成モニターとして広く 用いられている。しかし, 中性粒子の検出に際 しては, イオン化室での親ガスの解離イオン化 による中性ラジカルとの干渉が問題になる ${ }^{17)}$ 。 優れた粒子選別性を持つ R I S を併用する事に より，これらの問題点は解決されるであろう。 この手法を応用して, Squire 等は, Table I の波長333.4 nm の共鳴線を用いて, MOCVD の $\mathrm{Al}$ 原子源として用いられるトリメチルアルミ の加熱基板上での熱分解の様子を詳しく調べて いる ${ }^{18)}$ 。

質量分析器を利用する RIS は高真空を必要 とする。比較的高い圧力（数Torr $\sim 1$ 気圧）下 での RISによる $\mathrm{CH}_{3}$ の検出例としては, Chou による 1 気圧の $\mathrm{CH}_{4} / \mathrm{Ar} / \mathrm{He}$ 混合ガス中での パイロリシスにより発生した $\mathrm{CH}_{3}$ ラジカルの検 出と ${ }^{19)}$, Meier 等による低圧（１0 Torr）の $\mathrm{CH}_{4}-\mathrm{O}_{2}$ フレーム中での $\mathrm{CH}_{3}$ の検出がある ${ }^{28)}$ 。 いずれも Table I の $333.4 \mathrm{~nm}$ 及び $286 \mathrm{~nm}$ での $2+1$ イオン化過程を利用している。前者 では, 検出器に一対のワイヤー電極を用いて,
Table IV Partial list of two photon transitions of $\mathrm{CH}_{3}$ for $2+1$ RIS $^{16)}$.

\begin{tabular}{llll}
\hline \hline & & Wavelength & $\begin{array}{c}\text { Two photon } \\
\text { energy } \\
\left(\mathrm{cm}^{-1}\right)\end{array}$ \\
\hline $3 p^{2} A^{\prime \prime}{ }_{2}$ & $0_{0}^{0}$ & 333.4 & 59972 \\
& $2_{1}^{1}$ & 329.4 & 60700 \\
& $2_{0}^{2}$ & 319.1 & 62660 \\
& $1_{0}^{1}$ & 317.9 & 62886 \\
& $2_{1}^{3}$ & 315.6 & 63355 \\
$4 p^{2} A_{2}^{\prime \prime}$ & $2_{0}^{\mathbf{4}}$ & 306.2 & 65300 \\
$4 f^{2} E^{\circ}$ & 286.3 & 69837 \\
$5 f^{2} E^{\prime}$ & $0_{0}^{0}$ & 275.75 & 72508 \\
\hline \hline
\end{tabular}

エネルギー $0.8 \mathrm{~mJ}$ の333.4 $\mathrm{nm}$ 光を焦点距離 $50 \mathrm{~cm}$ のレンズで集光している。この時の推定検 出感度は数 $\mathrm{ppm}\left(\sim 10^{13} \mathrm{~cm}^{-3}\right)$ と報告されている。 一方後者では, 励起エネルギー $1 \sim 2 \mathrm{~mJ}$ を用 いて, 検出下限 $10^{12} \mathrm{~cm}^{-3}$ 程度が得られている。 $\mathrm{CH}_{3}$ や $\mathrm{SiH}_{3}$ などの場合, $2+1$ イオン化過程 については 2 光子励起断面積やイオン化断面積 に関して定量的なデータはほとんどないので, ここに挙げた例は検出下限の目安になろう。

\section{$3.2 \mathrm{SiH}_{3}, \mathrm{GeH}_{3}$ ラジカル}

$\mathrm{CH}_{3}$ と同様非発光性である $\mathrm{SiH}_{3}, \mathrm{GeH}_{3}$ につ いても最近 Johnsonらにより $2+1$ イオン化過 程によるR I Sスペクトルが報告されている ${ }^{21,22) 。 ~}$ 実験装置は基本的には Fig. 2 のものと同様で ある。すなわち，フローリアクターで生成した ラジカルをR I Sによりイオン化した後, TOF 型の質量分析器で検出する。観測された $\mathrm{SiH}_{3}$ と $\mathrm{GeH}_{3}$ の励起スペクトルの例をそれぞれ Fig. 3 と Fig. 4 に示す。 $\mathrm{SiH}_{3}$ の場合は, 370 400 $\mathrm{nm}$ にかけて, $\mathrm{GeH}_{3}$ の場合は 380〜420 nmに かけて畿つかの振動バンドが見られる。ちなみ にこのときの励起条件は, 励起エネルギー 5 〜 $10 \mathrm{~mJ}$, 焦点距離 $250 \mathrm{~mm}$ レンズで集光してい る。 


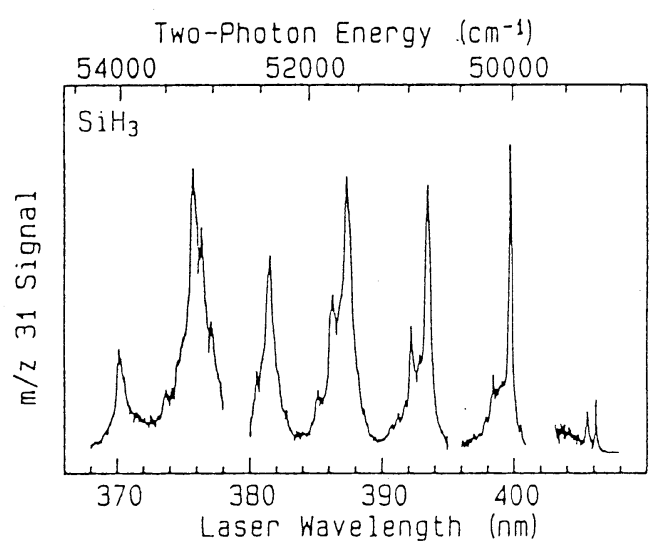

Fig. 3 RIS spectrum of $\mathrm{SiH}_{3}{ }^{211}$.

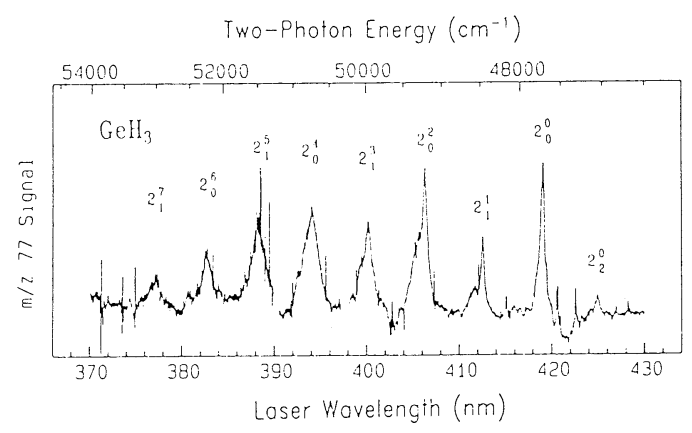

Fig. 4 RIS spectrum of $\mathrm{GeH}_{3}{ }^{22)}$.

\section{RIS の素過程計測への応用}

RIS を最初に反応や拡散など気相中での素過 程計測へ応用したのは, Hurstらによるアルカ リ金属原子を対象とする測定である ${ }^{23)} 。 \mathrm{CH}_{3}$ や $\mathrm{SiH}_{3}$ については, RIS スペクトルが最近同定 された程度であり，素過程計測が試みられた例 はないようである。本節では，RIS の高い時間 ・空間分解能を利用して我々の行なっている $\mathrm{CH}_{3}$ ラジカルの反応係数測定の試みを中心に紹 介する。

\section{1 反応係数測定への応用}

\section{$4.1 .1 \mathrm{CH}_{3}$ ラジカルの生成と検出}

これまで $\mathrm{CH}_{3}$ については, 波長 $216 \mathrm{~nm}$ での 紫外吸収による計測が行なわれている24,25)。し かし，この波長域はＣＶＤ䨌囲気中では他のガ スによる干渉を受け易い。最近は, 半導体レー
ザーによる赤外吸収も試みられている ${ }^{26)}$ 。吸収 法に比べ，RIS は空間分解能に優れているので 素過程計測に適している。

実験装置の構成を Fig. 5 に示す。装置は, 以前LIF による $\mathrm{C}_{2}$ ラジカルの拡散係数の測定 に用いたものを，RIS 用に改造した ${ }^{27-29) 。 す な ~}$ わち, 真空容器内に封入した母材ガスを $\mathrm{ArF}$ ーザーによるフラッシュホトリシスで光解離し， 生成したラジカルの時間・空間変化を測定し て, 反応や拡散係数を決定する。ホトリシス用

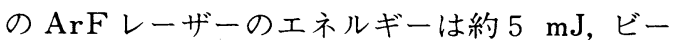
厶径は $5 \mathrm{~mm} \phi$ である。 $\mathrm{CH}_{3}$ 発生用の母材ガスに は， $\mathrm{Ar}$ で希勫したアセトン $\left(\mathrm{CH}_{3} \mathrm{COCH}_{3}\right)$ ま たはメタノールを用いた。アセトンは, $193 \mathrm{~nm}$ の $\mathrm{ArF}$ レーザー光の吸収により，

$$
\begin{aligned}
\mathrm{CH}_{3} \mathrm{COCH}_{3}+\mathrm{h} \nu & \rightarrow \mathrm{CH}_{3} \mathrm{CO}+\mathrm{CH}_{3} \\
\mathrm{CH}_{3} \mathrm{CO} & \rightarrow \mathrm{CH}_{3}+\mathrm{CO}
\end{aligned}
$$

の 2 段階過程により解離し， 2 個の $\mathrm{CH}_{3}$ ラ ジカルを発生する ${ }^{30)}$ 。

$\mathrm{CH}_{3}$ ラジカルは, 波長 $333.4 \mathrm{~nm}$ での $2+1$ イオン化過程により共鳴イオン化した。発生し たイオン・電子対は, 容器内に挿入したガード 電極付きの平行平板電極で捕集し，バッフアー

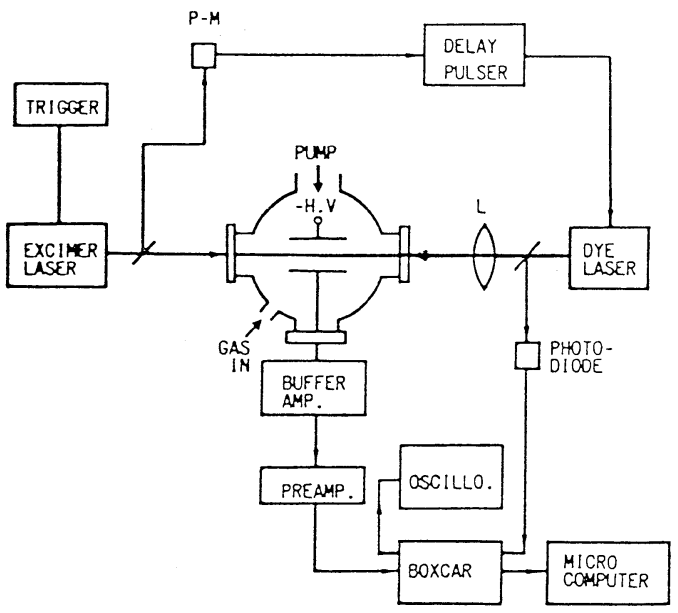

Fig. 5 Experimental setup used for the RIS detection of $\mathrm{CH}_{3}$. 
アンプ, プリアンプで増幅後, ボックスカー積 分器で積算平均し, データはマイクロコンピュ ータに記録した。RIS 用のプローブレーザーに は，KrFレーザー励起の DMT 色素レーザーを 用いた。測定部での色素レーザー光のエネルギ

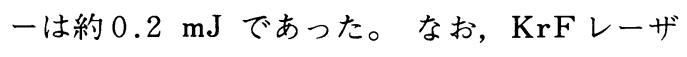
一励起の場合, 励起光による色素セルの光損傷 が起こり易いので, 可能ならば波長 $667 \mathrm{~nm} の$ 色素レーザー光の第二高調波を用いるのが実用 的である。

Fig. 6 に典型的な信号波形例を示す。最初

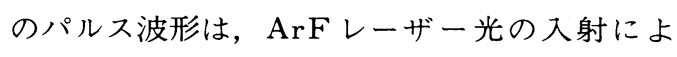
るものであり, 二つ目のパルスがRISによる信 号波形である。 $\mathrm{CH}_{3}$ ラジカル密度の時間変化は, 2 台のレーザー発振のタイミングを変化して測 定できる。

発振のタイミングを固定して測定した $\mathrm{CH}_{3}$ ラ ジカルの励起スペクトルの例を，Fig. 7 に示す。 罒にみられる鋭いピークは, 以下のような実験 事実から， $\mathrm{CH}_{3}$ のRISによる信号と同定した。 すなわち, その波長が $\mathrm{CH}_{3}$ ラジカルの 2 光子共 鳴波長と一致しており, その信号強度は励起レ ーザーパワーの 3 乗に比例して増加し, 3 光子 イオン化によることが確認された。また, 解離 用 $\mathrm{ArF}$ レーザー光を入射しない時にはこの信 号は観測されず，信号が解離生成物に起因する

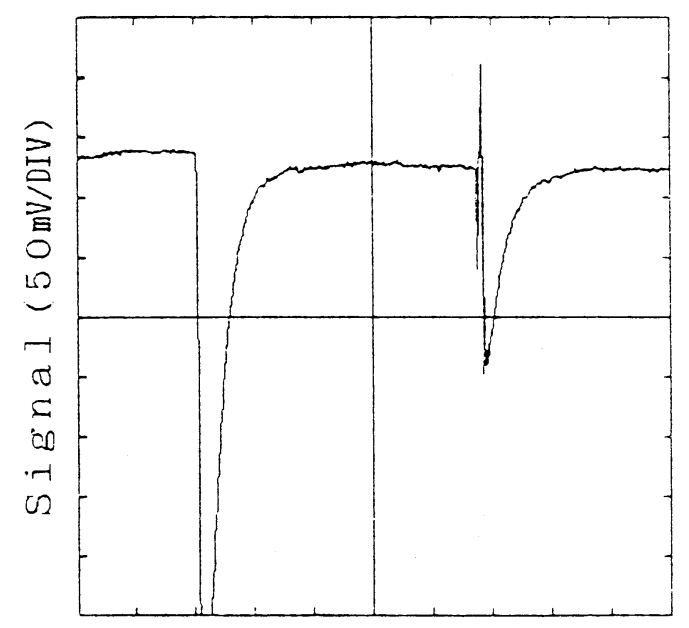

Time ( 10 us/DIV)

Fig. 6 Typical signal pulse shape (right hand side).
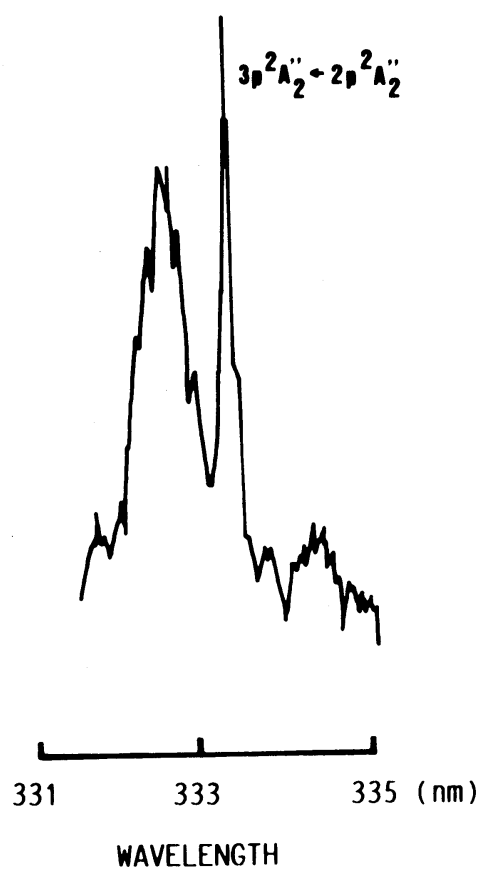

Fig. 7 Excitation RIS spectrum of $\mathrm{CH}_{3}$.

ことを示していた。一方, 短波長側のプロード なスペクトルは, ArFレーザー光を入射しな い時にも観測され，母材ガス自身か母材ガスに 含まれる不純物の多（おそらく 3 または 4 ）光 子イオン化によるものである。

RIS では効率よくイオン化を行なうため, LIF などに比べ一般に強い励起を必要とする。 このため CVD気相のように多種の分子ガスを 含む雲囲気での RIS では，上述の例のように 励起スペクトルで分子間の干渉が起こり易い。 質量分析器を併用できれば, 選択性と検知感度 は大幅に改善できる。しかし, $\mathrm{GeH}_{3}$ などの場 合は $\mathrm{Ge}$ 原子の同位体存在比のために $\mathrm{GeH}_{n}(n$ $=1 \sim 3 ）$ の区別は困難であり, 同定に当たっ ては注意を要する。

\section{4. $1.2 \mathrm{CH}_{3}$ ラジカル密度の時間変化}

ArF レーザーと色素レーザーの発振の夕イ ミングを変化させて励起スペクトルを測定し， $\mathrm{CH}_{3}$ ラジカル密度の時間変化を測定した。結果 をFig. 8 に示す。Fig. 8 には信号強度の逆数 


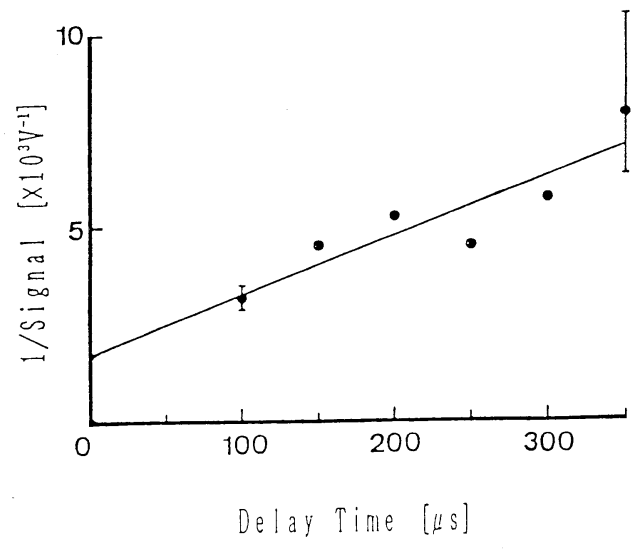

Fig. 8 Intensity of $\mathrm{CH}_{3}$ RIS signal as a function of time after photolysis.

が時間の関数として示してある。これから $\mathrm{CH}_{3}$ 密度は時間に逆比例して減少していることが分 かる。 $\mathrm{CH}_{3}$ 密度のこの時間変化は, $\mathrm{CH}_{3}$ が再結 合により減少していると考えれば理解できる。 この時, $\mathrm{CH}_{3}$ 密度の時間変化は,

$$
1 / n=k t+1 / n_{0}
$$

で与えられる。ここで, $k$ は再結合速度係数, $n_{0}$ は解離直後の $\mathrm{CH}_{3}$ 密度である。式(2)の関係 により最小自乗法によるフイッテイングを行な つた結果が, Fig. 8 に実線で示してある。

Fig. 8 で, $\mathrm{CH}_{3}$ 密度の絶対値が分かっている ならば，直線の傾きより再結合速度係数 $k$ を決 定することができる。しかし， R I Sによる測 定から直接密度の絶対值を決定することができ なかったので，アセトンの ArFレーザー光に 対する吸収断面積 $\sigma$ と反応(1)に対する量子収率 $\eta$ を用いて, 初期 $\mathrm{CH}_{3}$ 密度 $n_{0}$ を推定した。測定 部での解離直後の $\mathrm{CH}_{3}$ 密度は,

$$
n_{0}=2 N E \quad \eta \quad \sigma \exp (-N \sigma L) / \pi R^{2} h \nu
$$

で与えられる。ここで, $E$ は ArFレーザー光 のエネルギー, $h \nu$ ArFレーザーの光子エネ

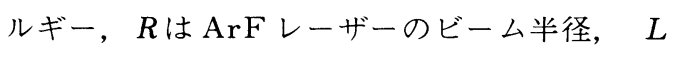
は入射空から測定部までの距離， $N$ はアセトン の密度である。吸収断面積 $\sigma$ は, 実験により $\sigma$ $=3.2 \times 10^{-18} \mathrm{~cm}^{2}$ と求まった。量子収率 $\eta$ には,
Brouard らによる值 $\eta=0.96$ を用い ${ }^{25)}$, 実験 条件 $E=3.5 \mathrm{~mJ}, L=205 \mathrm{~mm}, \quad R=2.5 \mathrm{~mm}$, $N=1.8 \times 10^{15} \mathrm{~cm}^{-3}$ を代入して, 初期 $\mathrm{CH}_{3}$ 密度 $n_{0}$ は $1.7 \times 10^{14} \mathrm{~cm}^{-3}$ と推定された。この值と, Fig. 8 の結果より, 再結合係数として $k=5.3$ $\times 10^{-11} \mathrm{~cm}^{3} / \mathrm{s}$ が求まる。この值は, Macpherson らによる值 $k=3.79 \times 10^{-11} \mathrm{~cm}^{3} / \mathrm{s}$ と良く 一致している ${ }^{24)}$ 。

また初期密度より検出下限は, $5 \times 10^{13} \mathrm{~cm}^{-3}$ 程度と推定された。この下限は, 信号及び背景 雑音の摇らぎにより制限されているので, 信号 の積算を行なえば（本実験では 3 回）さらに検 出下限を下げることができよう。

先に我々は $\mathrm{C}_{2}$ のLIF 計測においてプローブ 光ビームを空間的にスキャンして $\mathrm{C}_{2}$ 密度の空間 分布より拡散定数の決定を行なった ${ }^{28)}$ 。同様の 手法がこの場合にも適用できる。

\section{2 付着係数測定への応用}

素過程に関する量の中で基板表面へのラジカ ルの付着係数は, CVD 過程では成膜速度と直 接関係しており最も興味ある量の一つである。 しかし, その測定の困難さからラジカルの付着 係数を測定した例はほとんどないのが実状であ る。最近, Robertson とRossi はRISを利用 して $\mathrm{SiH}_{2}$ の付着係数の測定を報告している ${ }^{31)}$ 。

Fig. 9 に彼らの実験装置を示す。測定原理 は, 容器内に閉じ込められたラジカルの密度は, 気相衝突反応が無視できるとすると, 容器壁面 での付着係数に依存して減少することを利用す る。容器内に閉じ込めた圧力 $1 \times 10^{-3}$ Torr 程 度の $\mathrm{C}_{4} \mathrm{H}_{9} \mathrm{SiH}_{3}$ ガスを $\mathrm{CO}_{2}$ レーザーにより多 光子解離し, $\mathrm{SiH}_{2}$ ラジカルを発生する。 $\mathrm{SiH}_{2}$ ラジカルは容器壁との衝突を繰り返す内, 壁面 への付着によりその密度が減少する。密度の時 間変化を RIS により計測して, 壁面への衝突頻 度より付着係数を算定する。 Robertsonらは, 容器壁を $\mathrm{C}_{4} \mathrm{H}_{9} \mathrm{SiH}_{3}$ を用いた光 $\mathrm{CVD}$ によりア モルフアス $\mathrm{SiC}$ 膜でコーティングして, その膜 面上での $\mathrm{SiH}_{2}$ の付着係数として室温の $\mathrm{SiH}_{2}$ で 0.1 , 振動励起された $\mathrm{SiH}_{2}$ で0.5程度と見積っ 


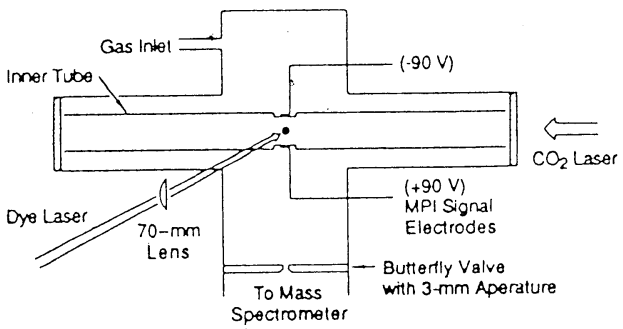

Fig. 9 Experimental setup used for the measurement of the sticking coeficient of $\mathrm{SiH}_{2}$ by $\mathrm{RIS}^{31 \text { ) }}$.

ている。

付着係数は, 基板の表面状態や基板がプラズ マにさらされている状態では異なった值となる。 このような手法での測定だけではなく，実際の 条件を模擬した測定法の開発を行なっていく必 要がある。

\section{5. 材料キャラクタリゼーションへの応用}

前節までは，RISによる気相中のラジカルの 検出と気相素過程計測への応用について述べた。 この他にも, プロセス関連分野へのレーザーイ オン化法の応用として，CVDで作成した膜の 分析など材料キャラ.クタリゼーションへの応用 が期待されている。これはプラズマプロセスの 計測とは直接関係ないけれども, 重要な応用分 野であるのでここで簡単に述べる。

固体材料のキャラクタゼーション法として, 2 次イオン質量分析法 (SIMS) に代表される 質量分析法が広く用いられている。質量分析器 にレーザーイオン化を組み合わせたレーザー質 量分析法 (LIMS) は, 金属, 半導体, セラミ ック，高分子などの固体材料から気体まで各種 材料に適用可能で, 高感度な局所測定が可能な 分析法として知られている。

LIMS の原理的な構成法は, Fig. 2 の装置と 同様であるが，質量分析器にはQMの他に飛行 時間分解型 (TOF) も用いられる。固体の分 析法では，材料の気化法とイオン化法の組合せ でいくつかの構成法がある。最も簡便なのは, 固体表面に直接レーザー光を照射して, 気化と イオン化を同時に行なうレーザー脱離質量分析
法 (LDMS: Laser Desorption Mass Spectroscopy）やレーザーマイクロプローブ質量分 析法 (LMMS : Laser Microprobe Mass Spectroscopy）である。一方，気化とイオン 化を分離したものには，イオンビームなどで気 化した気体を強力なレーザー光で非共鳴的に多 光子イオン化を行なうSALI (Surface Analysis by Laser Ionization) と ${ }^{32)}$, RIS を用い る SIRIS (Sputter Initiated RIS) がある ${ }^{33)}$ ただし，いずれの場合も絶対濃度は測定できな いので，絶対值は標準資料との比較により較正 する。

質量分析器にTO F を用いるLDMS やSALI は, レーザー分光法が不得手な多元素同時分析 が可能なことに特長がある。レーザーイオン化 では, 一般に各元素のイオン化効率の違いによ り元素間で相対検出感度が異なる。これを避け るには，イオン化過程が飽和するほどレーザー 光強度を高めれば良い。従って, SARI ではイ オン化用レーザーとして, 短波長であるため 2 から 3 光子で全ての原子をイオン化でき, しか も高出力が得られるエキシマーレーザーが用い られる。

SIRISでは質量分析器は必ずしも必要ないが, 通常はS N 比を高めるために併用されることが 多い。RIS の絶対検出感度は原子 1 個を検出で きるほど高いので, SIRISの感度はおもにスパ ッタリングにより発生できる原子数で決まって いる。相対検出感度を $1 \mathrm{ppb}$ としても，1原子 層のみのスパッタリングでも十分であり, 特に 表面のキャラクタリゼーションに有効である。 バルクの相対検出感度としては，例えばSi中の $\mathrm{Fe}$ の場合500 ppt が得られている34)。

LIMS は固体材料の分析以外にも，プロセス で用いられる超高純度ガス中の不純物にも有力 な検出法となる。これらの測定ではしばしば多 原子分子が測定対象になるが，電子ビームやプ ラズマによるイオン化を利用した従来の質量分 析器では, 解離によるフラグメント化が起きて 多原子分子のままの測定は困難である。

LIMS では, 最近コーヒーレントVUV光を用い 


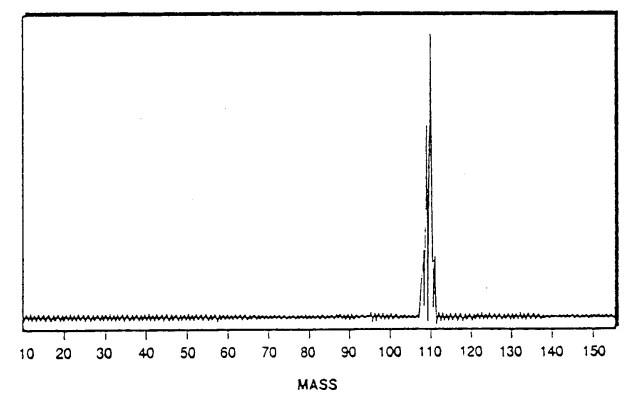

Fig. 10 Picosecond laser induced TOF mass spectrum of $\mathrm{CH}_{3} \mathrm{SeCH}_{3}{ }^{36}$ ).

たソフトイオン化やピコ秒レーザーを用いて解 離が起こる以前にイオン化を終了するなど新し い手法が開発されつつある ${ }^{35,36)}$ 。Fig. 10 にジメ チルセレン $\left(\mathrm{CH}_{3} \mathrm{Se} \mathrm{CH}_{3}\right)$ をピコ秒レーザー によりイオン化した場合の質量スペクトルを示 す。フラグメント化を起こすことなく $\mathrm{CH}_{3} \mathrm{Se}$ $\mathrm{CH}_{3}$ を検出できているのが分かる。

\section{6.おわりに}

レーザーイオン化法のプラズマプロセス関連 分野への応用について述べた。特に，RISによ るラジカル種の検出と素過程計測への応用につ いて, $\mathrm{CH}_{3}, \mathrm{SiH}_{3}$ などの非発光性ラジカルの 測定を中心に述べた。プラズマ内部の状態を高 い空間分解能でその場測定することに関しては, レーザーイオン法 (LIS) はLIFなどに比べ魅 力に之しい。しかし, LIS は全ての原子・分子 に適用可能であり，検出感度も高いので，気相 素過程や表面素過程の計測をはじめ, 材料や作 成した資料のキャラクタリゼーションなど，各 種プロセス分野でますます重要な計測法になっ て行くと思われる。

九大での実験に協力された安藤宏行, 森山芳 雄氏に感謝します。

\section{参考文献}

1) W. Demtröder : Laser Spectroscopy Springer-Verlag, Berlin (1982).

2) 秦 信宏, 松田彰久, 田中一宜：応用物理 54 (1984) 208.

3）田久保嘉隆：レーザー研究 15 （1987） 215.
4）橘 邦英：分光研究 37 (1988) 142.

5) G. S. Hurst, M. G. Payne, S. D. Kramer and J. P. Young : Rev. Mod. Phys. 51 (1976) 767.

6) G. S. Hurst and M. G. Payne: Principles and Ap plications of Resonance Ionization Spectroscopy, Adam Hilger, Bristol and Philadelphia (1988).

7）宮崎健創：レーザー研究 11 (1983) 257.

8) R. A. Gottscho and C. E. Gaebe : IEEE Trans. Plasma Sci. PS-14 (1986) 92.

9) B. N. Ganguly, J. R. Shoemaker, B. L. Preppernau and A. Garscadden : J. Appl. Phys. 61 (1987) 2778.

10) S. W. Downey, A. Mitchell and R. A. Gottścho : J. Appl. Phys. 63 (1988) 5280.

11) U. Brinkmann : Laser Focus No.65 (1988) 79.

12) C. Chen, B. Wu, A. Jiang and G. You : Sci. Sinica (Ser. B) 28 (1985) 235.

13) K. Kato : IEEE J. Quantum Electron. QE-22 (1986) 1031.

14) T. G. DiGiuseppe, J. W. Hudgens and M. C. Lin : Chem. Phys. Lett. 82 (1981) 267.

15) T. G. DiGiuseppe, J. W. Hudgens and M. C. Lin : J. Chem. Phys. 76 (1982) 3337.

16) J. W. Hudgens, T. G. DiGiuseppe and M. C. Lin : J. Chem. Phys. 79 (1983) 571.

17) H. Toyoda, H. Kojima and H. Sugai : Appl. Phys. Lett. 54 (1989) 1507.

18) D. W. Squire, C. S. Dulcey and M. C. Lin : Chem. Phys. Lett. 116 (1985) 525.

19) M. -S. Chou : Phys. Lett. 114 (1985) 279.

20) U. Meier and K. Kohse-Hoinghaus : Chem. Phys. Lett. 142 (1987) 498.

21) R. D. Johnson. III and J. W. Hudgens : Chem. Phys. Lett. 141 (1987) 163.

22) R. D. Johnson III , B. P. Tsai and J. W. Hudgens : J. Chem. Phys. 89 (1988) 4558.

23) L. W. Grossman, G. S. Hurst, S. D. Kramer, M. G. Payne and J. P. Young: Chem. Phys. Lett. 50 (1977) 297.

24) M. T. Macpherspn, M. J. Pilling and M. C. Smith : Chem. Phys. Lett. 94 (1983) 430.

25) M. Brouard, M. T. Macpherson, M. J. Pilling, J. M. Tulloch and A. P. Williamson : Chem. Phys. Lett. 113 (1985) 413.

26) C. Yamada, E. Hirota and K. Kawaguchi : J. Chem. Phys. 75 (1981) 5256.

27) T. Okada, T. Nishigoori, Y. Kajiyama and M. Maeda : Appl. Phys. B44 (1987) 175.

28) T. Okada, Y. Kajiyama, H. Andou and M. Maeda : Appl. Phys. B47 (1988) 191.

29) 岡田龍雄, 梶山義夫, 安藤宏行, 森山芳雄, 梶 原寿了, 前田三男, 村岡克則, 赤崎正則：レー ザー研究 17 (1989) 136.

30) E. L. Woodbridge, T. R. Flectcherand S. R. 
Leone : J. Phys. Chem. 92 (1988) 5387.

31) R. M. Robertson and M. J. Rossi : Appl. Phys. Lett. 54 (1989) 185.

32) C. H. Becker and K. T. Gillen : Anal. Chem. 56 (1984) 1671.

33) J. E. Parks, H. W. Schmitt, G. S. Hurst and W. M. Fairbank, Jr. : Thin Solid Films 108 (1983) 69.
34) J. E. Parks and M. T. Spaar : J. Crystal Growth 89 (1988) 4.

35) D. Feldmann, J. Kutzner, J. Laukemper, S. MacRobert and K. H. Welge : Appl. Phys. B44 (1987) 81.

36) R. Larciprete and M. Stuke : J. Crystal Growth 77 (1986) 235. 